\title{
Raised Gravel Beaches as Proxy Indicators of Past Sea-Ice and Wave Conditions, Lowther Island, Canadian Arctic Archipelago
}

\author{
DOMINIQUE ST-HILAIRE-GRAVEL, ${ }^{1,2}$ TREVOR J. BELL ${ }^{1}$ and DONALD L. FORBES ${ }^{1,3}$
}

(Received 16 April 2009; accepted in revised form 5 November 2009)

\begin{abstract}
This study investigates whether raised beach sequences preserved on emergent coasts of the central Canadian Arctic Archipelago contain a proxy record of past sea-ice conditions and wave intensity. We hypothesize that periods of reduced sea ice (increased open water) expose shorelines to more prolonged and higher wave energy, leading to better-developed beach ridges. Surveys of raised beach sequences on Lowther Island revealed the following patterns: a) high, wide, single- to multicrested barriers backed by deep swales or lagoons characterize both the active and lowest relict shorelines; $b$ ) small, narrow, discontinuous ridges of poorly sorted gravel extend from 1.0 to $7.5 \mathrm{~m}$ asl, except from 4.5 to $5.0 \mathrm{~m}$ asl; c) ridge morphology is similar to the active and first relict ridges between 7.5 and $11 \mathrm{~m}$ asl; d) a near-featureless zone with minor terraces and ridges above $11 \mathrm{~m}$ extends to above $30 \mathrm{~m}$ asl. These distinct morphological and sedimentary units are interpreted as a function of wave climate and thus of summer sea-ice conditions. This model suggests periods of greater wave activity from the present day back about $500{ }^{14} \mathrm{C}$ years $\left(530\right.$ cal BP; Unit A), during a short interval from 1750 to $1600{ }^{14} \mathrm{C}$ years $\mathrm{BP}(1750-1450 \mathrm{cal} \mathrm{BP}$; Unit $\mathrm{B}^{\prime}$ ), and earlier from 2900 to $2300{ }^{14} \mathrm{C}$ years BP (3030-2340 cal BP; Unit C). Units B and D are interpreted as the result of more severe ice conditions with lower wave energy from 2300 to $500{ }^{14} \mathrm{C}$ years $\mathrm{BP}(2340-530 \mathrm{cal} \mathrm{BP})$ and earlier from more than 5750 to $2900{ }^{14} \mathrm{C}$ years BP $(6540-3030 \mathrm{cal}$ BP). Discrepancies with previously published interpretations of regional sea-ice history may reflect the local nature of the beach proxy record, which implies occurrences of extensive open-water fetch east and west of Lowther Island but cannot be extrapolated to a regional scale. The beach record shows distinct variation through time and provides an alternative window on past summer ice extent in central Barrow Strait.
\end{abstract}

Key words: beach morphology, gravel beach, sea ice, climate history, Canadian Arctic

RÉSUMÉ. Cette étude cherche à déterminer si les plages de graviers soulevées présentes sur les côtes émergentes de l'archipel Arctique canadien renferment des informations sur les conditions passées de glace de mer et d'intensité des vagues. Nous émettons l'hypothèse que les périodes de réduction de la glace de mer (plus d'eau libre) exposent les rivages à une plus grande énergie des vagues et pour une plus longue durée conduisant à des crêtes de plage mieux développées. Les données récoltées sur les plages soulevées de l'île Lowther révèlent les tendances suivantes : a) de hautes et larges barrières de gravier comprenant une ou plusieurs crêtes et associées à des lagunes profondes caractérisent le rivage moderne et les plus récents rivages anciens; b) de petites crêtes étroites et discontinues composées de graviers mal triés sont présentes entre 1,0 et 7,5 m d'altitude, avec une exception entre 4,5 et 5,0 m d'altitude; c) entre 7,5 et $11 \mathrm{~m}$ d'altitude, la morphologie côtière est similaire à ce que l'on retrouve sur le rivage moderne et les plus récents rivages anciens; d) la section comprise entre 11 et $30 \mathrm{~m}$ d'altitude est caractérisée par un faible nombre de crêtes et de terrasses de bas relief. Ce modèle suggère des périodes de plus grande énergie des vagues entre 500 années ${ }^{14} \mathrm{C}$ BP et l'actuel (530 cal. BP; Unité A), lors d'un court intervalle entre 1750 et 1600 années ${ }^{14} \mathrm{C}$ BP $(1750-1450$ cal. BP; Unité B'), et entre 2900 et 2300 années ${ }^{14} \mathrm{C}$ BP (3030-2340 cal. BP; Unité C). Les Unités B et D sont interprétées comme étant des périodes où les conditions de glace étaient plus prononcées et où l'énergie des vagues était restreinte entre 2300 et 500 années ${ }^{14} \mathrm{C}$ BP $\left(2340-530\right.$ cal. BP) et entre un minimum de 5750 et 2900 années ${ }^{14} \mathrm{C}$ BP $(6540-3030$ cal. BP). Les divergences dans l'histoire régionale de la glace de mer avec les interprétations publiées antérieurement peuvent refléter la nature locale de la morphologie côtière, signifiant que la présence d'étendues d'eau libre à l'est et l'ouest de l'île Lowther ne peut pas être extrapolée à l'échelle régionale. La morphologie des plages soulevées montre des variations distinctes à travers le temps et fournit une fenêtre alternative sur l'histoire de l'étendue de la glace de mer dans le détroit de Barrow.

Mots clés : morphologie côtière, plage de gravier, glace de mer, histoire du climat, Arctique canadien

\footnotetext{
${ }^{1}$ Department of Geography, Memorial University of Newfoundland, St. John's, Newfoundland A1B 3X9, Canada

${ }^{2}$ Corresponding author: dsthilaire@mun.ca

${ }^{3}$ Geological Survey of Canada, Natural Resources Canada, Bedford Institute of Oceanography, PO Box 1006, Dartmouth, Nova Scotia B2Y 4A2, Canada

(C) The Arctic Institute of North America
} 


\section{INTRODUCTION}

Severe ice conditions plagued many expeditions seeking the Northwest Passage in the 18th and 19th centuries, while recent years have witnessed remarkable expansion of summer open water. Longer records of varying ice conditions through the Holocene have been interpreted from micropaleontological proxy indicators, ice-core geochemistry, and the spatial and temporal distribution of whale remains on former shorelines in the Canadian Arctic Archipelago (CAA) (e.g., Dyke et al., 1996; Mudie et al., 2005; Kinnard et al., 2006). Extensive gravel beach deposits, now raised above sea level by postglacial isostatic uplift, mark the former shoreline positions in many areas, and these show considerable variability in scale and development.

Close to $90 \%$ of the Canadian coastline is exposed to sea ice, which can greatly affect shore-zone morphology and sedimentology (Taylor and McCann, 1983). The effects of sea ice may be protective, constructive, or erosive. Protection may occur through limitation of wave development (lack of open water) or through persistence of an ice cover (ice foot and anchor ice) on the beach when open water develops offshore. Constructive effects may take the form of beach nourishment by onshore movement of sediment carried or pushed by ice. Erosive effects may result from ice ride-up and beach scour, melt-out, or nearshore grounding and wallow (Forbes and Taylor, 1994). Because of the impact of sea ice on beach morphology, we hypothesize that in regions of isostatic uplift and falling relative sea level (RSL), a postglacial record of sea-ice conditions may be preserved in raised-beach sequences (Fig. 1).

One of the principles of the morphodynamic approach in coastal geomorphology is that large-scale forms and processes change slowly, tend to respond to long-term changes in forcing, and filter out high-frequency events (Wright and Thom, 1977). We can therefore expect the morphology of raised gravel beach sequences to reflect general trends in wave energy and not simply the last major event. For example, Sanjaume and Tolgensbakk (2009) examined raised beach ridges on the Varanger Peninsula in Arctic Norway and concluded that differences in the number of ridges between sites could be explained by intrinsic factors such as wave energy, beach and offshore gradient, volume of sediment supply, size of sediments, and coastal evolution with strong self-organization. The role of sea ice in the geomorphology of modern and raised polar beaches has also been recognized by Butler (1999) from studies in McMurdo Sound, Antarctica.

Although raised-beach sequences have received little attention in the context of past variations in sea-ice conditions, raised coastal deposits have been used to decipher past climate variability. For instance, Berkman et al. (1998) used the macrofossil content of raised marine deposits to infer early Holocene climatic variations in Antarctica. Other studies have interpreted the presence or absence of raised coastal features as evidence for late Quaternary variation of the West Spitsbergen Current (Brückner et al., 2002;

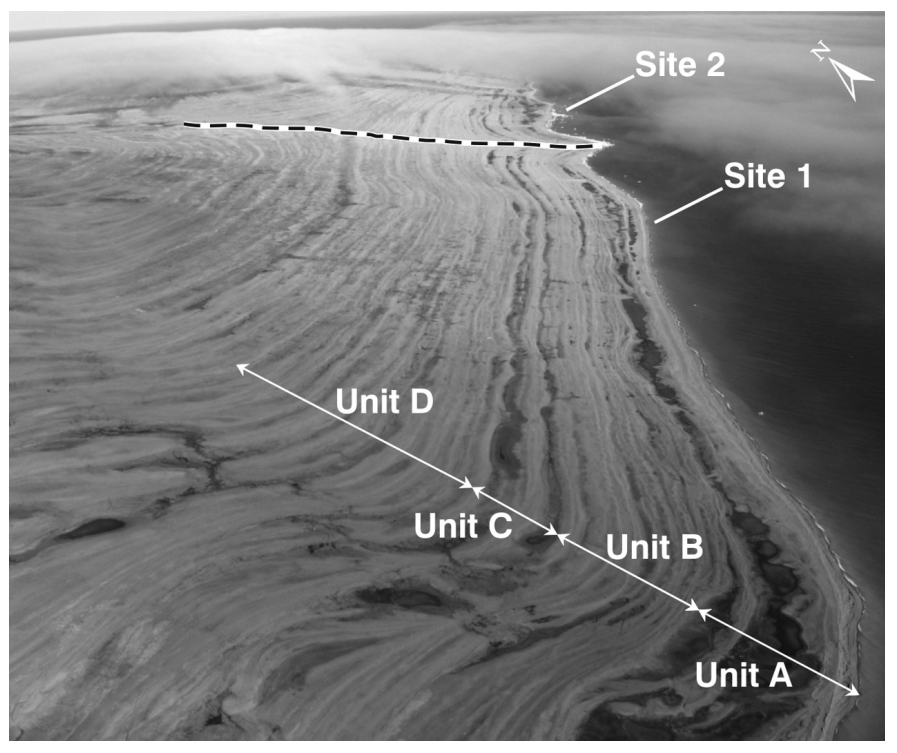

FIG. 1. Oblique aerial photograph of the east coast of Lowther Island, central CAA, showing raised-beach sequences formed under falling relative sea level during the late Holocene. Sites 1 and 2 are located approximately 2 and $4 \mathrm{~km}$ from the camera. The upper limit of Unit D is at $30 \mathrm{~m}$ asl. See Table 1 for detailed description of study sites and units. The broken line marks the course of the river between sites.

Brückner and Schellman, 2003). Fletcher et al. (1993) and Møller et al. (2002) used morphological variations within raised-beach sequences as a proxy record for fluctuations in the Polar Front during the late Quaternary. Mason and Jordan (1993) interpreted erosional truncations of beach ridges along the Alaskan coast as a proxy record of storms, and Møller et al. (2002) interpreted the presence of raised boulders on uplifted relict beaches on the Kola Peninsula, Russia, as proxy indicators for past episodes with more sea ice.

We hypothesize that the morphology and, to some extent, the sedimentology of gravel beaches record the palaeo-environmental conditions that prevailed during beach formation and can therefore act as proxy indicators of past coastal forcing (wave or ice-related processes responsible for beach formation). In particular, we consider beach ridge size, continuity, and morphology as measures of wave forcing combined with sediment supply. The height of a beach ridge is a measure of wave runup. Therefore, in this study, we interpret high, wide, smooth, and laterally continuous beach ridges as products of wave action during periods of less extensive or less persistent sea ice. Small, narrow, discontinuous and hummocky beach ridges are considered as products of small waves during intervals of more severe sea-ice cover. In some but not all cases, the size, roundness, and sorting of beach sediments may also support this interpretation.

This paper has two goals: first, to consider whether the processes forming Arctic beaches leave a record of past forcing in present beach form and composition. The second and more specific objective is to test the hypothesis that raised-beach morphology and, to a lesser extent, sedimentology, are useful proxies for long-term variability in summer sea-ice conditions near Lowther Island in central Barrow Strait. 


\section{Arctic Gravel Beach Morphology}

It is widely accepted that storm-wave runup is the dominant process leading to the formation of gravel beach ridges (e.g., Orford, 1977; Fletcher et al., 1993; Møller et al., 2002). However, little is known about the mechanisms that lead to the generation of individual ridges under a falling sealevel regime (Forbes et al., 1995; Orford et al., 2002). The formation of gravel beaches under stable or rising RSL has received more attention, especially since the early 1980s (e.g., Carter and Orford, 1984; Carter et al., 1989; Forbes et al., 1995; Orford et al., 1991, 1996, 2002). From these studies, four related controls on gravel beach morphology have been recognized: (1) sediment source and supply, (2) rate and direction of sea-level change, (3) basement topography, and (4) wave climate. In high latitudes, sea ice can be added as a fifth control.

Sediment source and supply are major controls on gravel barrier morphology (Forbes and Syvitski, 1994; Orford et al., 1996). Sediment source determines the type of sediment and the origin of the sediment transport pathway. Abundant sediment supply has been correlated with the development of multi-ridge complexes (Carter and Orford, 1984, 1993; Orford et al., 1991), whereas the development of massive solitary ridges through ridge consolidation is attributed to a decaying sediment supply (Carter and Orford, 1984; Orford et al., 1996).

Relative sea-level change (direction and rate) plays an important role in access to sediment sources and affects the rate of sediment supply (Forbes and Syvitski, 1994). Where sediment supply is abundant and longshore currents are effective, large beach-ridge complexes can form under falling or rising RSL (e.g., Wells, 1996; González Bonorino et al., 1999). Where large river sources are absent, rising RSL settings that promote coastal erosion and the longshore supply of sediment may provide the greatest potential for extensive beach-ridge formation (Forbes et al., 1995; Teller, 2001). In contrast, falling RSL results in progressive abandonment of coastal features and a seaward shift in the wave base. This shift brings more sediment on the seabed within the reach of wave action, providing a potential source for the beach formation (McKenzie, 1958; Carter, 1988). The relative importance of this source will depend on the nature of the seabed material and the quantity of sediment supplied from other sources alongshore. As an existing ridge gradually grows higher relative to mean sea level, it will be overtopped less and less often and will ultimately become inactive. Abandonment may also result from formation of a new ridge on the seaward side. Initiation of the next ridge may occur through development of a swash bar or may result from ice push to form an initial ridge that may subsequently be reworked by waves. As sea level falls, progressively shoaling bathymetric features on the shoreface will cause changes in wave refraction and longshore sediment transport (Melville, 1984). These changes combined with the underlying topography at the coast can lead to variations in beach orientation and sporadic development of small spits (Fig. 1, foreground).
Thus the bathymetry and underlying basement topography constitute another important control on coastal morphology: they affect the height, angle, and breaking characteristics of waves (Jennings and Smyth, 1990; Cooper and Navas, 2004), regulate the supply of sediment (Orford et al., 1996), provide resistant anchor and hinge points for barrier growth and wave refraction (Orford et al., 2002), and dictate the ratio between sediment availability and space available for deposition - the accommodation space (Roy et al., 1994). For a given volume of sediment, a gentle slope encourages the development of a wide but thin, often multi-crested barrier characteristic of prograding systems, whereas a steep slope promotes thick and narrow (consolidated) forms (Roy et al., 1994). Bathymetry may also influence ridge height through its impact on nearshore wave energy (Forbes and Taylor, 1987; Orford et al., 1991, 1996, 2002). According to this model, greater ridge height develops where a steep nearshore slope allows bigger waves to break close to or on the foreshore, particularly if these are spilling breakers that promote wave runup and overtopping (Orford, 1977).

In temperate regions, morphological changes at the coast occur most commonly during storm events characterized by the coincidence of high water level (combined tide and surge) and wave activity (Orford, 1977). In Arctic environments, the timing of storms relative to sea-ice concentration is a key factor because the spatial distribution of sea ice controls the potential for wave generation and propagation. Taylor (1981) observed that the character and extent of nearshore ice and its interaction with waves determine to some extent the magnitude of change on Arctic gravel beaches during storms. He observed that 6 to 14 second waves 1 to $3 \mathrm{~m}$ in height were "completely attenuated by bands of first and second year ice of greater than $100 \mathrm{~m}$ width and $6 / 10$ concentration, or by a 15 to $20 \mathrm{~m}$ wide barricade of grounded ice boulders" (Taylor, 1981:147). Despite the prevalence of ice in the study area, storm waves can be effective beach-forming agents when sufficient open-water fetch is available. Their impact during any one storm event depends on the initial condition of the beach and specific wave conditions. During a 1969 storm at Radstock Bay, Devon Island, McCann (1973) found that 3-4 second waves $1 \mathrm{~m}$ high built a ridge at the high-water mark, while 6-7 second waves $1.5 \mathrm{~m}$ high subsequently removed the recently deposited ridge and combed down the whole beach face. A storm that occurred on 20-23 July 2007 off the southwest corner of Cornwallis Island, where there was extensive open water, resulted in beach-ridge accretion at sheltered sites and significant wave erosion at exposed sites (St-Hilaire et al., 2007). The coastline had only marginally recovered from the impact of this event three weeks after the storm.

Sea ice in the coastal environment can have protective, constructive, or erosive impacts. The predominant effect of sea-ice cover on the shoreline is to severely decrease the potential for wave development and propagation and thereby to limit wave action at the shoreline (Dionne, 1976; Hume and Schalk, 1976; Moign, 1976; Owens, 1976; Taylor and McCann, 1976, 1983; Forbes and Taylor, 1994). 
Ice in the nearshore can protect a beach even when open water is present offshore (Taylor and McCann, 1976; Taylor, 1981). The early development of an ice layer on the beach during freeze-up commonly leads to formation of an ice foot (Owens and McCann, 1970) that can protect the beach during storms. The ice foot may persist for some time after spring break-up, protecting the beachface from early summer storms (Moign, 1976; Taylor and McCann, 1983; Barnes et al., 1993; Orford et al., 2002). As a consequence of highly subdued wave and current action during periods of extensive ice cover, longshore sediment transport is inhibited. In extreme cases, perennial sea ice results in poorly developed or largely absent beach forms, as exemplified in the northwest CAA (Taylor and Forbes, 1987; Dyke and England, 2003).

Ice-limitation of wave action reduces rates of sediment reworking in the surf zone. Thus it is reasonable to suppose that beach sediments would undergo less abrasion (less rounding) and less size sorting under ice-bound conditions. Butler (1999) found a negative correlation between sea-ice duration and sediment sorting and rounding on modern beaches of McMurdo Sound, Antarctica. Time intervals with more extensive sea ice are therefore likely to be represented in raised beaches by less rounded and more poorly sorted sediment (more angular and with a wider range of grain sizes).

Ice interaction with the coast can be a disruptive process (Dionne, 1976, 1992 and references therein; Taylor, 1978a; Forbes and Taylor, 1994), especially along coasts exposed to long wind and wave fetches (Owens and McCann, 1970; Taylor and McCann, 1976). Ice-push processes leave a recognizable morphology, such as thrust scours and mounds. Ice-melt features are typically encountered as mounds and pits (Owens and McCann, 1970; Dionne, 1976; Forbes and Taylor, 1994). Offshore, the scouring action of sea ice is the dominant seabed erosion process on the inner shelf of the southern Beaufort Sea (Héquette and Barnes, 1991).

Reimnitz et al. (1990) argued that onshore movement of sea ice with associated nearshore scour is a constructive process, moving sediment landward to build up the beach. Textural inversions, such as ice-rafted boulders deposited on gravel beaches or a crest of unsorted sediment on a wellsorted beach ridge, are depositional features that may be preserved in the geological record (Martini, 1980).

It has been argued that these sea-ice processes do not affect overall beach morphology and are short-lived because only those features above the storm-wave limit are likely to survive subsequent wave action (Owens and McCann, 1970; Forbes and Taylor, 1994). Notwithstanding these preservation constraints, Taylor and McCann (1976) found numerous ice-push scars and mounds on the raised beaches of northern Somerset Island and southwest Devon Island. Raised ice-push ridges and mounds were also described in the Arctic by Washburn (1947) and in Antarctica by Nichols (1961). Nevertheless, periglacial processes and wave reworking reduce the preservation potential of sea-ice features on raised beaches. The simple presence or absence of relict sea-ice features may therefore be an unreliable indicator of past sea-surface conditions.

In summary, sea ice has a significant effect on Arctic beach morphodynamics through its impact on wave climate and as a direct agent of sediment transport and shore-zone reworking. A morphological and sedimentological analysis of raised-beach sequences should therefore present evidence for periods of low sea-ice intensity in the form of larger wave-formed ridges with better sorted and rounded clasts if other controlling factors remain constant.

\section{REGIONAL SETTING}

\section{Geology and Geomorphology}

Lowther Island occupies a central location in Barrow Strait in the central CAA (Fig. 2). It is $20 \mathrm{~km}$ long by $9 \mathrm{~km}$ wide and dome-shaped, with the highest point at $162 \mathrm{~m}$ asl on the north end of the island. The island is composed of resistant carbonate rocks, mostly dolomite, ranging in age from Upper Silurian to Lower Devonian. Sandstone, siltstone, limestone and gypsum are also found in the Disappointment Bay Formation that crosses the island along a NW-SE transect (Thorsteinsson, 1986). The island has a thin but extensive till cover that was deposited by the Laurentide Ice Sheet during the Wisconsinan glaciation. The till has an average of $10 \%$ to $50 \%$ stone content, mostly sourced from local carbonate rocks (Dyke, 1993).

Taylor (1978b) presents a general overview of the coastal geomorphology of Lowther Island. Except for short sections of high rock cliffs, the island is bordered by flights of raised gravel beaches (Fig. 1). The modern beach ridges are larger on the east side of the island, reflecting greater wave exposure on that side due to a combination of more frequent open water and longer over-water fetch (Fig. 2).

\section{Relative Sea-level History}

The Holocene RSL history of Lowther Island is well constrained by radiocarbon dating of driftwood (67\%), bowhead whale (Balaena mysticetus) bones (17\%), and shells $(16 \%)$ collected from raised marine deposits (Fig. 3; Dyke et al., 1991; Dyke, 1993). One additional bowhead whale ear bone not included in previous compilations provided a radiocarbon age of $4295 \pm 20{ }^{14} \mathrm{C}$ BP (UCIAMS-29238), corrected for ${ }^{13} \mathrm{C}$ fractionation to a base of $-25 \%$. The whale skull was located at $18.5 \mathrm{~m}$ asl near the southeastern corner of the island $\left(74^{\circ} 29.5^{\prime} \mathrm{N}, 97^{\circ} 30.3^{\prime} \mathrm{W}\right)$. Notwithstanding the issue of marine reservoir corrections for whale bone radiocarbon dates in the CAA (cf. Dyke, 1993), there is very good correspondence between index points derived from driftwood and whale bone on Lowther Island. As a result, the emergence curve is well constrained, especially below $60 \mathrm{~m}$ asl, and "among the best available for the central Arctic Islands" (Dyke, 1993:141). The marine limit was established at $106 \mathrm{~m}$ asl on Lowther island around $9500{ }^{14} \mathrm{C} \mathrm{BP}$, 


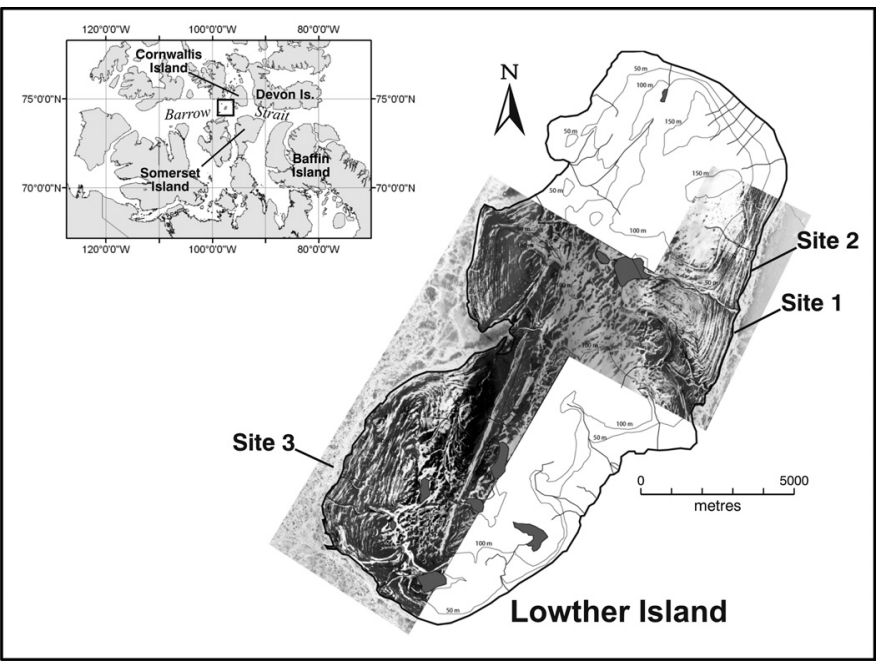

FIG. 2. Location of Lowther Island (black square, inset map), central CAA, and of the three study sites. Background is a QuickBird satellite image from 2006 (contains material (C) DigitalGlobe).

and beaches below $60 \mathrm{~m}$ and $30 \mathrm{~m}$ asl are younger than 8000 and $5000{ }^{14} \mathrm{C} \mathrm{BP}$, respectively.

The chronological control on beach ridge formation for this study relies on the assumption that the RSL history of Lowther Island is sufficiently well constrained that a specific age can be attributed to a beach ridge on the basis of its elevation. Some limitations to this assumption need to be discussed. First, it may be incorrect to attribute ${ }^{14} \mathrm{C}$ ages to a coastal landform from its elevation alone because of horizontal and vertical errors that are not accounted for in the RSL curve. For instance, driftwood can be locked for many years within the ice pack prior to deposition (Dyke et al., 1997) or, as a result of ice ride-up or ice pile-up, may be deposited several metres above mean sea level (Forbes and Taylor, 1994). Moreover, deposition of driftwood through normal wave processes can also result in vertical (height) errors on the order of 1-2 $\mathrm{m}$ or more due to storm surge or wave activity at the time of deposition. Therefore horizontal and vertical errors related to sea-level indicators can expand the envelope of the RSL curve by several metres and tens to hundreds of years (Fig. 3).

Second, it can be difficult to fix the exact position of past sea level in relation to a relict landform. On Lowther Island, the crest of the present active storm berm is approximately 1.5 to $2 \mathrm{~m}$ above present mean sea level. A large difference between sea level and crest height may represent a period of low sea-ice conditions. It is expected therefore that this difference will change as sea-ice conditions, and hence wave climate, change through time. The lack of precision in tying sea-level elevation to coastal landforms translates into a similar lack of precision when attributing an age to a landform. This challenge was addressed by choosing the elevation of the swale or trough behind a given beach ridge as an objective and consistent elevation reference in relation to each relict landform.

For these reasons, and because this study focuses on the later part of the Holocene (i.e., the past $6 \mathrm{ka}$ ), we have

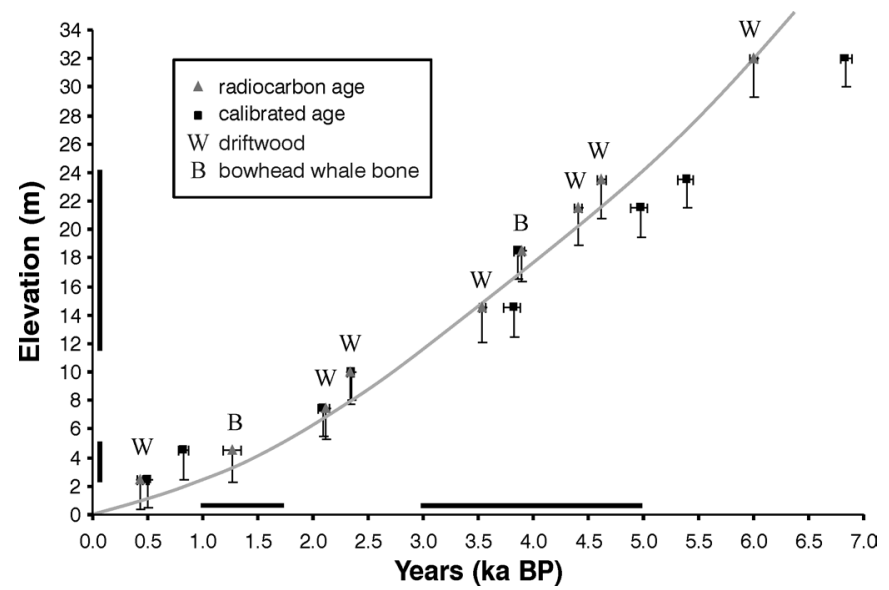

FIG. 3. Late Holocene relative sea-level curve for Low ther Island reconstructed from radiocarbon-dated driftwood and bowhead whale bones (Dyke, 1993; this study). Thick black lines along the horizontal axis represent periods of light sea-ice conditions as derived from the spatio-temporal distribution of bowhead whale bones on raised marine deposits of Barrow Strait and Peel Sound (Dyke et al. 1996). Thick black lines along the vertical axis represent the elevation ranges for raised beaches that correspond to periods of lighter sea-ice conditions, according to the reconstructed RSL history.

used a modified and truncated version of the RSL curve for Lowther Island (Fig. 3). Horizontal error bars represent the 1 -sigma error term from the dating laboratories. The vertical error bars account for the reach of wave run-up and sea-ice processes, estimated at $2 \mathrm{~m}$, but do not incorporate sampling or elevation errors. The resulting interpreted RSL curve is used to attribute an age range to morphological units at the study sites on Lowther Island.

\section{Past Sea-ice Conditions}

Various Holocene reconstructions of past sea-surface conditions in the Arctic Ocean have been proposed through the use of proxy indicators such as dinocysts (Levac et al., 2001; Mudie et al., 2005), diatoms (deSève, 1999; Katsuki and Takahashi, 2005), and ice-core chemistry (Grumet et al., 2001; Kinnard et al., 2006). Variations in summer seaice conditions in the central CAA have been inferred from the spatio-temporal distribution of bowhead whale remains and driftwood stranded on raised beaches. According to Dyke et al. (1996), local sea-ice history for Barrow Strait can be divided into five time intervals based on summer sea-ice conditions:

- Year-round severe sea-ice conditions prevailed from 8250 to $5000{ }^{14} \mathrm{C}$ BP $(9340-5780$ cal BP), 3000 to $1750{ }^{14} \mathrm{C}$ BP $\left(3280-1750\right.$ cal BP), and $1000{ }^{14} \mathrm{C}$ BP to present $(940-0$ cal BP), correlating with the absence of bowhead whale remains.

- Conversely, summer sea-ice conditions were less severe than today between 5000 and $3000{ }^{14} \mathrm{C}$ BP $(5780-3280 \mathrm{cal} \mathrm{BP})$ and 1750 and $1000{ }^{14} \mathrm{C} \mathrm{BP}(1750-$ 940 cal BP), permitting incursions of whales (Fig. 3). 
A recent study uses the abundance of a sea-ice biomarker in marine sediment cores to reconstruct Holocene seaice history for Barrow Strait (Vare et al., 2009). According to this study, spring sea-ice occurrence was at its lowest from ca. 10000 to $6000 \mathrm{cal} \mathrm{BP}$, increased steadily between ca. 6000 and $4000 \mathrm{cal} \mathrm{BP}$ (remaining below median for the Holocene), increased rapidly between ca. 4000 and $3000 \mathrm{cal}$ $\mathrm{BP}$, and remained at its highest value between about 3000 and $400 \mathrm{cal}$ BP (with some evidence for a small decrease between approximately 1200 and $800 \mathrm{cal} \mathrm{BP}$ ). It is inappropriate to draw comparisons between the reconstructed sea-ice history of Vare et al. (2009) and this study. The biomarker used by Vare and collaborators records localized spring (April-May) sea-ice conditions at a site approximately $200 \mathrm{~km}$ east of Lowther Island. In this region, spring sea ice is a poor predictor of late-season open water. Most morphological change at the coast is expected to occur in the late summer and fall, when storm events are more likely to occur concurrently with open water.

\section{Coastal Oceanography}

Although there are no available records of wave climate or tidal range for the coast of Lowther Island, it is a predominantly low-energy coast with a semi-diurnal microtidal regime (Barrie et al., 1979). The approximate mean tidal range for the area is $0.55 \mathrm{~m}$, with a large (spring) tidal range of $0.79 \mathrm{~m}$. Potential (land-limited) wave fetches to the north and south are mostly less than $100 \mathrm{~km}$, whereas to the west and east they exceed $400 \mathrm{~km}$. Despite the relatively large potential fetch, wave formation and propagation are restricted by the presence of sea ice for 11 to 12 months of the year. Sea-ice data derived from weekly ice charts available on the Canadian Ice Service website (http://iceglaces.ec.gc.ca) indicate that summer sea-ice concentration is highly variable at Lowther Island. Between 1965 and 1976, open water allowed waves to rework the beaches for less than 37 days per year on average (Taylor, 1978b). Between 2001 and 2005, localized concentration of sea ice below six-tenths occurred for periods ranging from one to five weeks per year. Over the same period, open water (defined as one-tenth sea-ice cover or less) occurred only in 2001 (for one week) and 2005 (for two weeks). Low sea-ice concentrations are typically encountered from mid-August to late September. On average, the east side of the island experiences more days of open water than the west side. In 2006, when fieldwork for this study was undertaken, there was an exceptionally long season of extensive open water. The east side of Lowther Island was exposed to potential wave action for 11 weeks from late July to mid-October. Comparable conditions occurred in 2007, when the island was subject to open water for 10 weeks between late July and late September. Summer 2008 was yet another year of low sea-ice conditions, with open water surrounding Lowther Island for six weeks in August and September.

\section{METHODS}

\section{Study Sites}

Three sites were selected for this study following preliminary characterization of beach morphology using 1:60000 air photographs and Quickbird satellite imagery (Fig. 2). Sites 1 and 2 are located on east central Lowther Island, on either side of an incised river valley (Figs. 1 and 2). Both sites have an easterly exposure. The river located between Sites 1 and 2 acts as a sediment source characterized by a dominant southward longshore transport. Sites 1 and 2 were selected for their well-developed raised beaches, the southward longshore sediment transport, which consistently provided more sediment to Site 1 throughout the late Holocene, and the variation in beach morphology and sedimentology between the two sites. Site 3, located on the southwest corner of the island (Fig. 2), was selected for its westerly exposure, well-developed raised beaches, and the obvious morphological and sedimentological variations within the raised-beach sequence. Site 3 is located south of a small stream, which likely supplies sediment during the spring melt or heavy rain events. Sediment sources for all three study sites are varied and include reworking of thin glacial till and frost-shattered bedrock, ice-push sediment and possible wave transport from the nearshore zone, and inputs from nearby rivers. The maximum late-summer depth of the frost table is on average $0.53 \mathrm{~m}$ below the surface on modern beach ridges in this area (Taylor and Frobel, 2006).

\section{Geomorphology}

Topographic surveys of modern and raised beaches were conducted using real-time kinematic (RTK) Global Positioning System (GPS) receivers, which provided vertical and horizontal precision better than $0.1 \mathrm{~m}$.

Each of the three sites was surveyed extensively from the low-water mark to the highest well-preserved raised beach. With the exception of the modern shoreline, the morphology of raised beaches has been altered by periglacial processes, though with only minor effects on the mid to late Holocene sequence (30 $\mathrm{m}$ asl and below). Therefore, cross-shore surveys were restricted to the lower $30 \mathrm{~m}$, with the exception of two longer transects to an elevation of $90 \mathrm{~m}$ asl at Site 1 (data not shown here). Twelve regularly spaced cross-shore profiles (20 m apart) were surveyed at Site 1 and ten at Site 2 using the sampling intervals of $70 \mathrm{~cm}$ distance and $20 \mathrm{~cm}$ elevation in the GPS rover software. Ten cross-shore profiles (25 $\mathrm{m}$ apart) were surveyed at Site 3 using the same sampling intervals. Unless otherwise stated, the elevation of a raised coastal feature is given in metres above present mean water level and is based on the elevation of the swale or lagoon behind a given beach. The overall morphology of each beach ridge and its relationship to surrounding landforms were used to classify ridges into groups with distinctive characteristics. The form and scale of the ridges were the primary criteria used in the interpretation of forcing conditions. 


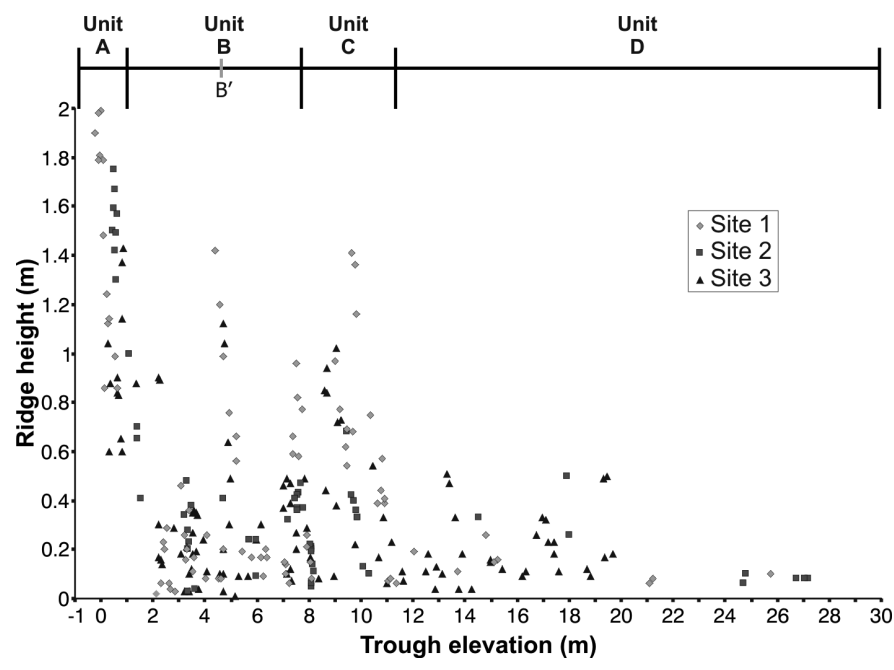

FIG. 4. Ridge heights measured on cross-shore profiles at Sites 1, 2, and 3 as a function of reference elevation (trough elevation) representing the approximate sea level at the time of ridge formation. Ridge height is defined as the vertical distance between a ridge crest and the next landward trough. The classification into units is shown across the top.

\section{Sedimentology}

Qualitative estimates of sediment size, shape, and roundness were obtained using digital images of a framed wire grid $(0.5 \times 0.5 \mathrm{~m})$ placed on the gravel surface at the ridge crest. With the predominant coarse pebble and fine cobble grain size, the images encompassed a typical sample size of well over one hundred particles. On average, 13 sediment photographs were taken per unit. Because of the high degree of weathering and cryoturbation of surface sediment, particularly on older beaches, sediment $10 \mathrm{~cm}$ beneath the surface was exposed for photography, except where sorted circles brought underlying gravel to the surface. Descriptions use terminologies established by Wentworth (1922) for sediment size and Powers (1953) for roundness. Qualitative estimates of sediment size sorting and roundness were used to complement the interpretation of forcing conditions from beach-ridge scale and morphology.

\section{Radiocarbon and Calendar Age}

Although most of the literature on postglacial sea-ice conditions in the CAA employs the radiocarbon timescale to report temporal patterns, results of this study are also presented in calendar years to conform to recent publication conventions. Radiocarbon-based age ranges on morphological units were calibrated using CALIB version $5.0 .2 \mathrm{html}$ (Stuiver et al., 2005). Because Dyke's (1993) RSL curve was largely based on driftwood samples, the atmospheric calibration data set INTCAL04 was used to derive calendar ages (Reimer et al., 2004). Although it is recognized that they are more accurately represented by age ranges, calibrated radiocarbon-based chronologies are reported as median-probability calibrated ages in calendar years before present (cal BP) and by convention are rounded to the nearest decade. Chronologies based on marine samples were calibrated in Calib 5.0.2html using the MARINE04 data set (Hughen et al., 2004), which incorporates a time-dependent global ocean reservoir correction of about 400 years. This correction is equivalent to the marine reservoir correction used by Dyke et al. (1996) and Mudie et al. (2005), whose chronologies required calibration for comparison with this study. Accordingly, the adjustment $(\Delta \mathrm{R})$ to accommodate local reservoir effects was set to zero in our calibration procedure.

\section{RESULTS}

Morphological and sedimentological analysis of raisedbeach sequences revealed consistent patterns of form and character within discrete elevation ranges that could be traced from one study site to another (Fig. 1).

Morphometric data on ridge height, defined as the vertical distance between each ridge crest and the next landward trough, showed a clear division of maximum ridge heights into two groups: $0.6 \mathrm{~m}$ or less and more than $0.6 \mathrm{~m}$ (Fig. 4). Units A (0.0-1.0 m asl), B' (4.5-5.0 m asl), and C (7.5-11 $\mathrm{m}$ asl) comprised high ridges; Units $\mathrm{B}(1.0-7.5 \mathrm{~m}$ asl excluding $\left.\mathrm{B}^{\prime}\right)$ and $\mathrm{D}(11-30 \mathrm{~m}$ asl) had low ridges (Fig. 5).

In Unit $\mathrm{A}$, all measured ridges are higher than $0.6 \mathrm{~m}$, with maximum ridge heights of $2.0 \mathrm{~m}$ at Site $1,1.75 \mathrm{~m}$ at Site 2, and $1.45 \mathrm{~m}$ at Site 3. In Unit $\mathrm{B}^{\prime}$, ridge heights reach $1.4 \mathrm{~m}$ at Site 1 and $1.1 \mathrm{~m}$ at Site 3, but Site 2 shows no high ridges. In Unit C, ridge heights reach $1.4 \mathrm{~m}$ at Site 1 and $1.0 \mathrm{~m}$ at Site 3, but only $0.7 \mathrm{~m}$ at Site 2. Units B and D had intervals with maximum ridge heights of less than $0.6 \mathrm{~m}$ and less than 0.3 , respectively (Fig. 4).

\section{Unit A $(0.0$ to $1.0 \mathrm{~m})$}

The local RSL curve (Fig. 3) indicates that this unit spans approximately the last 500 years. It includes the modern shoreline and the lowest relict beaches. Unit A is characterized by barriers that are narrow and single-crested at Sites 1 and 3, and wide and multi-crested at Site 2. These 20 to $60 \mathrm{~m}$ wide barriers are backed by prominent lagoons and swales that in places are partially infilled by washover fans and spit recurves (Fig. 6). Although the modern and relict barriers are separated at Site 1, they merge into a wide multi-crested barrier downdrift from the survey site (Fig. 1). The landforms of Unit A are relatively undisturbed by periglacial processes although narrow and shallow ice wedge troughs are visible on the first relict beaches. Sediment sorting and weathering by periglacial processes subsequent to deposition are also minimal.

The barriers forming the modern coastline are consistently larger than any of the raised beaches at Sites 1 and 2, and their crest heights of 1.5 to $2 \mathrm{~m}$ are equal to or higher than the first relict ridge on 22 of 30 cross-shore profiles (Fig. 5). At Site 1, the crest of the modern barrier is higher than the first relict ridge by 0.3 to $1.3 \mathrm{~m}$ over the entire study site. The crest height of the modern barrier is on average 
$0.25 \mathrm{~m}$ higher at Site 1 than at Site 2, where the crest rises toward the river. The modern barrier crest at Site 3 also rises toward the stream channel.

At all study sites, sediment composition shows little variability within Unit A and is best described as poorly sorted, angular to sub-angular pebble and cobble gravel. Scattered disc-shaped boulders occur on ridge crests.

\section{Unit B (1.0 to $7.5 \mathrm{~m})$}

Raised beaches located between 1.0 and $7.5 \mathrm{~m}$ asl (trough elevation) are numerous but narrow and characterized by low ridge relief (Fig. 1). They were likely deposited between 2300 and $500{ }^{14} \mathrm{C}$ BP $(2340-530$ cal BP). Their plan-view morphology commonly is sinuous, discontinuous, and truncated. They are lightly altered by periglacial and weathering processes in the form of ice-wedge polygons and weathering crusts on beach gravel. Original forms and sediment characteristics are well preserved despite these alterations.

The ridges are few and less than $0.5 \mathrm{~m}$ high at Site 2; at Sites 1 and 3 they are more abundant, but rarely exceed $0.4 \mathrm{~m}$ in height (Figs. 5 and 6). Sediment at Sites 1 and 3 is characterized by poorly sorted sub-angular to sub-rounded granule to cobble gravel; at Site 2, there is relatively wellsorted granule to pebble gravel.

One exception to this general pattern is the occurrence at all three sites of wide and continuous beach ridges at about 4.5 to $5.0 \mathrm{~m}$ asl, corresponding to an age range of 1600 $1750{ }^{14} \mathrm{C}$ BP (1460-1750 cal BP) (Figs. 5, 6, and 7). These ridges are $1 \mathrm{~m}$ high or higher at Sites 1 and 3 . They are characterized by better-sorted gravel and by a greater degree of roundness compared with adjacent ridges of Unit B. This sub-unit is labeled Unit B' on Figures 4 and 5.

\section{Unit $C(7.5$ to $11 \mathrm{~m})$}

Unit $C$ represents a period from approximately 2900 to $2300{ }^{14} \mathrm{C}$ BP $(3030-2340$ cal BP). The raised-beach morphology is characterized by high, wide, single-crested ridges backed by well-defined swales. The sharp morphological contrast with ridges comprising Units B and D is clearly visible on aerial photographs and satellite imagery (Figs. 1 and 2). Although well-developed polygon troughs are widespread at this elevation, original morphology and sediment composition are well preserved.

Unit $C$ is most obvious at Site 1, where a pair of barriers runs continuously for several kilometres. The barriers are backed by deep swales, partially infilled with washover fans, and can be traced across the river to Site 2 (Fig. 1). Overtopping fans and large ice pit features (more than $1 \mathrm{~m}$ across) are visible on the crest of ridges albeit in a degraded state. At Site 3, Unit C is composed of three continuous single-crest barriers backed by shallow swales partially infilled with washover fans.

Ridges of Unit $\mathrm{C}$ are characterized by relatively well sorted, sub-rounded gravel paved with disc-shaped cobbles and boulders.

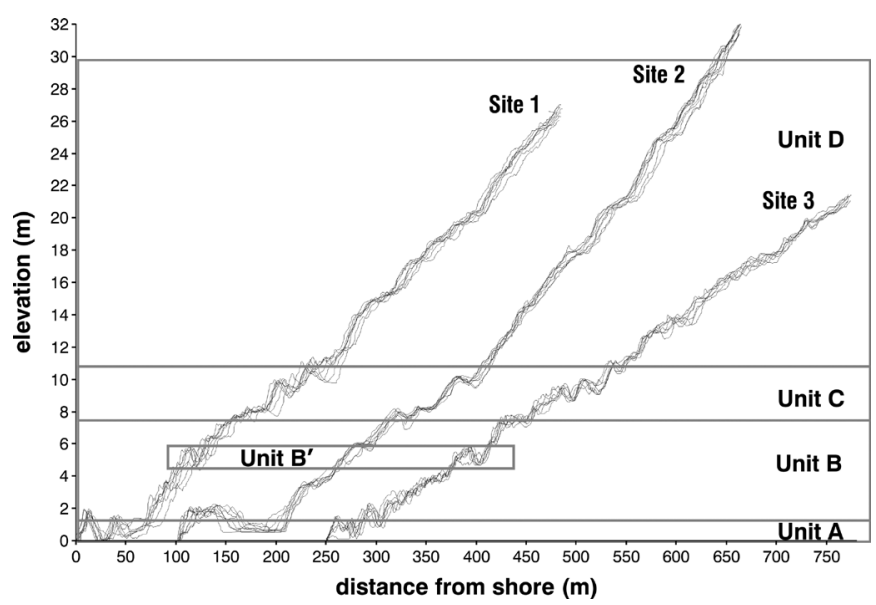

FIG. 5. Cross-shore topographic profiles at Sites 1 to 3. Eight or nine profiles are shown for each study site. Each set of profiles is offset horizontally by $100-150 \mathrm{~m}$ to avoid overlap. Vertical exaggeration on profiles is 16 times. Recurring trends in the morphological expression of beaches are superimposed on the four profile sets using rectangles. They are referred to as morphological units A to D, with a sub-unit (B') identified within Unit B.

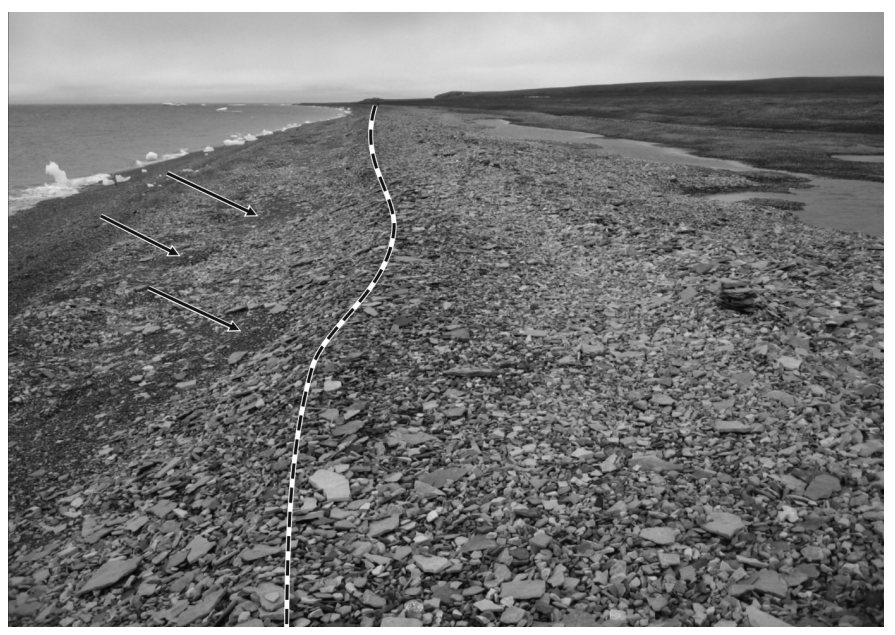

FIG. 6. Modern beach at Site 1 (looking south) is composed of a wide, singlecrested barrier and a lagoon partially infilled by spit recurves and overwash fans. Note the steep erosive upper foreshore (dashed line defines the beach crest) and the numerous ice-melt pits (arrows), approximately $0.5 \mathrm{~m}$ in diameter, on the lower foreshore.

\section{Unit D (11 $m$ and Higher)}

Unit D represents a period that ended about $2900{ }^{14} \mathrm{C} B P$ (3030 cal BP). The morphology of raised coastal landforms located above $11 \mathrm{~m}$ asl on Lowther Island is generally subdued and becomes progressively more altered by periglacial processes with increasing elevation and age. The original morphology and sediment composition of these landforms are in places significantly modified by processes such as creep, gelifluction, and sorting. The widespread occurrence of ice wedge troughs at lower elevation is replaced upslope by sorted circles at Site 1 (at $15 \mathrm{~m}$ asl) and Site 2 (at $8 \mathrm{~m}$ asl), and coincides with thinner coastal deposits over bedrock as observed in nearby river exposures. Ice-wedge polygons are well developed in a regular geometric pattern over the entire unit at Site 3. 

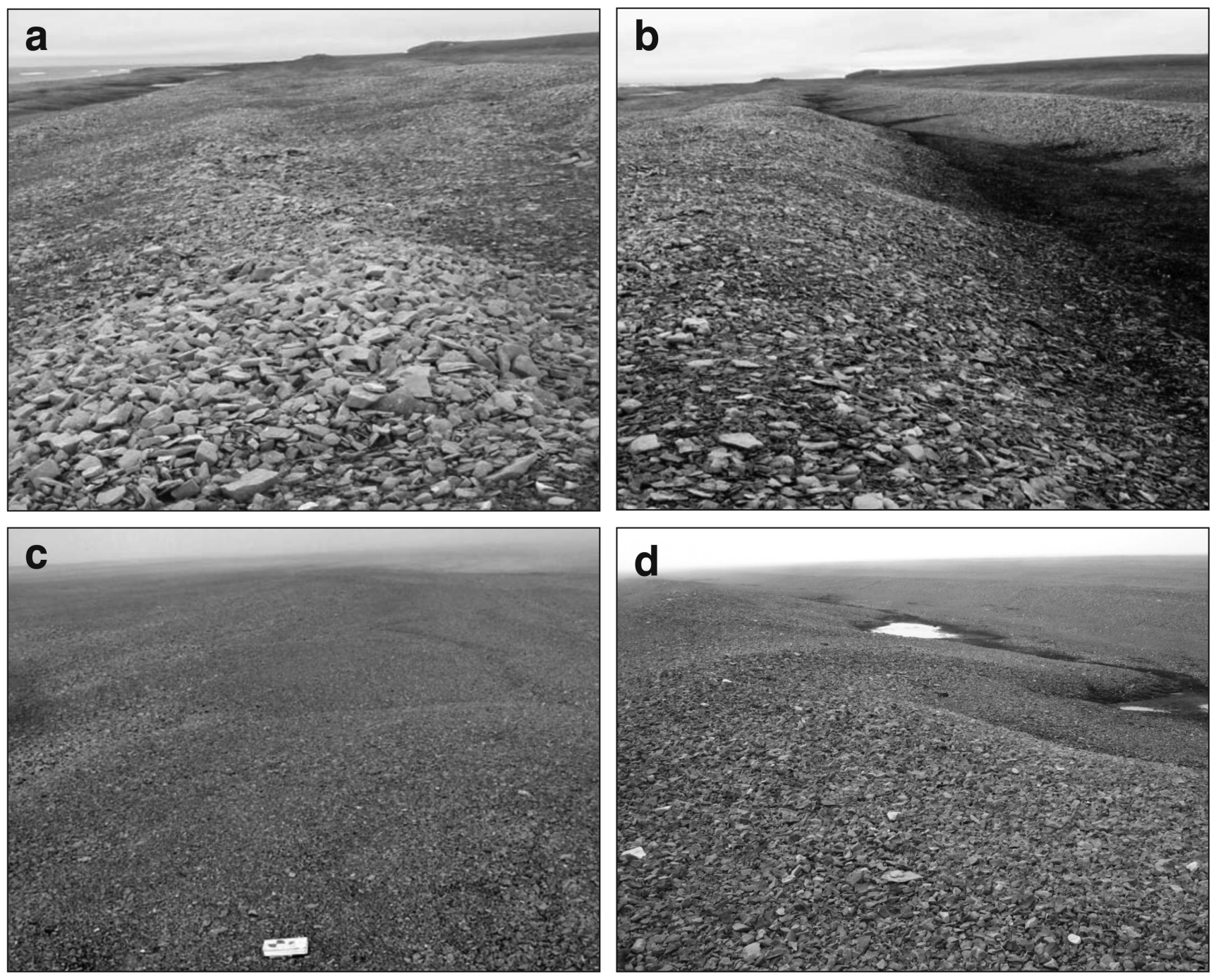

FIG. 7. Images of Unit B at sites $1(a, b)$ and $3(c, d)$. For the most part, Unit B is characterized by small, narrow discontinuous ridges composed of poorly sorted gravel. At Site 1, ice-pushed ridges of coarse, angular sediments are found on the ridge crests (a, foreground), whereas at Site 3, the ridges forming Unit B show very little relief (c). Significant morphological variations within Unit B justify the creation of a sub-unit B' characterized by well-developed beach and swale systems at Site 1 (b) and Site 3 (d). Similar variations are found at Site 2 (not shown).

A series of terrace-like steps characterizes Unit D at Sites 1 and 2. The terraces vary in width and height and are irregularly spaced with no obvious pattern. Sediment is mostly composed of poorly sorted, sub-angular gravel, ranging from coarse sand to boulders. At Site 3, Unit D is characterized by a few raised beaches and terraces of low amplitude. Most features at this site are discontinuous, hummocky, and composed of poorly sorted angular to subangular gravel. These are primarily depositional features, and cryoturbation is more limited at this site.

\section{DISCUSSION}

\section{Raised-beach Morphology and Sedimentology}

The morphology of late Holocene raised gravel beaches on Lowther Island shows common patterns that are classified into four distinct units.
The youngest unit (Unit A) is characterized by welldeveloped depositional features that likely result from a combination of relatively high wave energy and slow rates of RSL fall. RSL fell at an average rate of $2 \mathrm{~mm} / \mathrm{yr}$ over the past 500 years (Fig. 3, Table 1). This relatively slow trend of RSL due to progressively decreasing uplift and accelerated sea-level rise over the past century allowed wave and sea-ice processes to operate for a longer period of time at a given elevation, perhaps leading to the reworking of older deposits. Alongshore and between-site variations in beach morphology (single- or multiple-ridge barriers) within Unit A provide insight into the importance of local controls on the barrier morphology, such as accommodation space and sediment supply. Accommodation space at Site 2 is significantly smaller than at the other two sites because of its gentler slope (Table 1). The development of a wide multicrested barrier at Site 2 is consistent with conceptual morphodynamic models (e.g., Cowell and Thom, 1994). 
TABLE 1. Summary of beach elevation, morphology, and sedimentology, with slope values and rates of RSL change, for our three study sites on Lowther Island.

\begin{tabular}{|c|c|c|c|c|c|c|c|}
\hline & \multirow{2}{*}{$\begin{array}{l}\text { Elevation } \\
\quad(\mathrm{m})\end{array}$} & \multicolumn{2}{|c|}{ Morphology } & \multirow[b]{2}{*}{ Sedimentology } & \multirow{2}{*}{$\begin{array}{l}\text { Slope Value } \\
\text { at Site } 1\end{array}$} & \multirow{2}{*}{$\begin{array}{l}\text { Slope Value } \\
\text { at Site } 2\end{array}$} & \multirow{2}{*}{$\begin{array}{l}\text { Rate of RSL Fall } \\
\qquad(\mathrm{mm} / \mathrm{yr})\end{array}$} \\
\hline & & Plan View & Cross-shore & & & & \\
\hline Unit A & $0-1$ & $\begin{array}{l}\text { Continuous barriers, spit } \\
\text { recurves and overwash } \\
\text { fans partially infilling } \\
\text { lagoons. }\end{array}$ & $\begin{array}{l}1.5 \text { to } 2 \mathrm{~m} \text { high, } 20 \text { to } 60 \mathrm{~m} \\
\text { wide barriers. Single crest } \\
\text { at Sites } 1 \text { and } 3 \text {; multiple } \\
\text { crests at Site } 2 .\end{array}$ & $\begin{array}{l}\text { Poorly sorted, angular to } \\
\text { sub-angular pebble and } \\
\text { cobble with disc-shaped } \\
\text { boulders on ridge crests. }\end{array}$ & $0.02^{\circ}$ & $0.01^{\circ}$ & 2 \\
\hline Unit B & $1-7.5$ & $\begin{array}{l}\text { Sinuous, discontinuous and } \\
\text { truncated beaches. }\end{array}$ & $\begin{array}{l}\text { Numerous and narrow } \\
\text { beaches of low amplitude } \\
\text { at Sites } 1 \text { and } 3 \text {. Few small } \\
\text { beaches at Site } 2 \text {. }\end{array}$ & $\begin{array}{l}\text { Poorly sorted sub-angular } \\
\text { to sub-rounded granule } \\
\text { to cobble at Sites } 1 \text { and } 3 \text {. } \\
\text { Relatively well sorted at } \\
\text { Site } 2 \text {. }\end{array}$ & $0.1^{\circ}$ & $0.1^{\circ}$ & 3.3 \\
\hline Unit B' & $4.5-5$ & $\begin{array}{l}\text { Continuous barrier and } \\
\text { swale traceable in the } \\
\text { landscape for many } \\
\text { kilometres. }\end{array}$ & $\begin{array}{l}0.2 \text { to } 1.2 \mathrm{~m} \text { high, } 18 \mathrm{~m} \\
\text { wide, single-crested } \\
\text { barrier. }\end{array}$ & $\begin{array}{l}\text { Relatively well-sorted, } \\
\text { sub-rounded granule } \\
\text { to pebble paved with } \\
\text { disc-shaped cobbles and } \\
\text { boulders. }\end{array}$ & $0.1^{\circ}$ & $0.1^{\circ}$ & 3.3 \\
\hline Unit C & $7.5-11$ & $\begin{array}{l}\text { Continuous barrier and } \\
\text { swale traceable in the } \\
\text { landscape for many } \\
\text { kilometres. }\end{array}$ & $\begin{array}{l}0.6 \text { to } 1.1 \mathrm{~m} \text { high and } 22 \mathrm{~m} \\
\text { wide barriers. }\end{array}$ & $\begin{array}{l}\text { Relatively well-sorted, } \\
\text { sub-rounded gravel paved } \\
\text { with disc-shaped cobbles } \\
\text { and boulders. }\end{array}$ & $0.04^{\circ}$ & $0.04^{\circ}$ & 6 \\
\hline Unit D & $11+$ & $\begin{array}{l}\text { Continuous, subdued and } \\
\text { irregularly spaced beaches } \\
\text { and terraces. }\end{array}$ & $\begin{array}{l}\text { Near featureless section } \\
\text { between } 10.5 \text { and } 17 \mathrm{~m} \\
\text { asl. Small terraces at Sites } \\
1 \text { and } 2 \text {, small beaches at } \\
\text { Site } 3 \text {. }\end{array}$ & $\begin{array}{l}\text { Poorly sorted angular to } \\
\text { sub-angular gravel. }\end{array}$ & $0.07^{\circ}$ & $0.08^{\circ}$ & 7 \\
\hline
\end{tabular}

${ }^{1}$ Slope value at Site 3 is uniform at $0.04^{\circ}$ along the surveyed portion of the sequence.

Unit B covers a period of approximately 1800 years, during which RSL fell at an average rate of $3.3 \mathrm{~mm} / \mathrm{yr}$. The numerous occurrences and low amplitude of the raised coastal features, the poor sorting and rounding of the sediment, and the irregular morphology of raised gravel beaches forming Unit B testify to a low-energy environment that may be associated with more severe sea-ice conditions. In contrast, a well-developed ridge and swale system found across all sites at approximately $4.5-5 \mathrm{~m}$ asl indicates a brief change in the regional climate forcing around 1750 $1600{ }^{14} \mathrm{C}$ BP $(1750-1460$ cal BP). This change may be related to less severe sea-ice conditions, but the duration of more open water at this time is unclear.

Unit $C$ covers a period of approximately 600 years, during which RSL fell at an average rate of $6 \mathrm{~mm} / \mathrm{yr}$. Although similar in morphology to the barriers of Unit A, beaches and barriers composing Unit $\mathrm{C}$ are slightly smaller, which may be related to the faster rate of RSL fall. In this scenario, there would be less time for waves and sea-ice processes to transport and rework sediment at a given elevation. The overall morphology and sediment composition of beaches and barriers in Unit $\mathrm{C}$ indicate deposition under relatively high wave energy. The differences in size for the same beach ridges between Sites 1 and 2 highlight the importance of sediment supply in determining ridge size. Site 2, located updrift from the main source of sediment (Fig. 1), has consistently received less sediment than Site 1 during the late Holocene. This lower sediment supply at Site 2 is reflected in lower crest elevations (by 0.5 to $0.8 \mathrm{~m}$ ) in Unit $\mathrm{C}$ and a lower number of beach ridges in Units B and D. Although conceptual models (Forbes and Taylor, 1987; Orford et al., 1991, 1996, 2002) suggest that a gentler slope leads to lower ridge height, the reduction in slope in Unit $\mathrm{C}$ at Sites 1 and 2 (Table 1) corresponds to an increase in ridge height. In this case, it appears that wave climate and sediment supply prevailed over basement topography as the dominant control on beach morphology.

The upper end of Unit D is variable between sites but is taken as $30 \mathrm{~m}$ for the purpose of this discussion. This limit is equivalent to an age of about $5750{ }^{14} \mathrm{C}$ BP $(6540 \mathrm{cal} \mathrm{BP}$; Fig. 3). For the time span between 5750 and $2900{ }^{14} \mathrm{C}$ BP $(6540-3030 \mathrm{cal} \mathrm{BP})$, the rate of RSL fall averaged $7 \mathrm{~mm} /$ yr, diminishing from approximately $9 \mathrm{~mm} / \mathrm{yr}$ at $6000{ }^{14} \mathrm{C}$ BP (6840 cal BP) to about $5 \mathrm{~mm} / \mathrm{yr}$ around $3000{ }^{14} \mathrm{C}$ BP (3210 cal BP). Rapidly falling RSL limits the time available for deposition and reworking of the sediment. With limited sediment supply, falling RSL can lead to erosional staircases or high cliffs (Carter, 1988; Hansom, 2001). The progressive decrease in the rate of RSL fall may have contributed to the gradual morphological transition from predominantly erosional landforms (terraces) to depositional landforms (small ridges) within Unit $\mathrm{D}$. The morphological data suggest a 
period of severe sea-ice conditions, but higher rates of RSL fall may also have resulted in shorter durations for sediment reworking.

Sediment composition within a given raised-beach sequence does not vary extensively. This relative homogeneity is due to the proximity of the sediment source, the uniformity of the source material, and the relatively small amount of time available for sediment reworking by waves given the seasonal to potentially perennial sea-ice cover. Subtle differences can, however, be found between Units B and D, characterized by poorly sorted, mostly subangular gravel, and Units $\mathrm{B}^{\prime}$ and $\mathrm{C}$, which are composed of relatively well-sorted, sub-rounded gravel paved with disc-shaped cobbles and boulders. Unit A, which is composed of poorly sorted, angular to sub-angular pebble and cobble gravel with disc-shaped boulders on ridge crests, is an anomaly, which perhaps reflects the reworking of lower Unit B, increased sediment output from the river, ice-driven nourishment from the nearshore, or other factors.

\section{Reconstructed Sea-ice History}

Assuming that our age-elevation model is accurate and that barrier morphodynamics are related to sea-surface conditions, then the patterns of raised-beach morphology and sedimentology on Lowther Island can be interpreted in terms of late Holocene sea-ice history. Accordingly, a period of greater wave activity characterizes the modern era and may extend back about 500 years. Previous to this period, wave reworking on Lowther Island was more limited. This pattern suggests more severe ice conditions from 2300 to $500{ }^{14} \mathrm{C}$ BP $(2340-530$ cal BP), except for a short period of stronger wave activity around 1750 to $1600{ }^{14} \mathrm{C}$ BP (1750-1460 cal BP). Wave activity had also been higher from 2900 to $2300{ }^{14} \mathrm{C}$ BP (3030-2340 cal BP), following a period of lower wave activity between 5750 or earlier and $2900{ }^{14} \mathrm{C}$ BP $(6540-3030$ cal BP). The duration of higher wave energy in Unit A is unclear. It is possible, given the acceleration of global sea level rise in the past 100 years (Church and White, 2006) and the largely unweathered gravel, that the features in Unit A are much younger than 500 years.

The reconstructed wave and sea-ice history derived from the raised-beach sequences on Lowther Island is somewhat inconsistent with the sea-ice history interpreted from bowhead whale remains (Fig. 8; Dyke et al., 1996). In their reconstruction, Dyke et al. placed more open water in the Barrow Strait and Peel Sound region from 5000 to 3000 ${ }^{14} \mathrm{C}$ BP $\left(5780-3280\right.$ cal BP) and 1750 to $1000{ }^{14} \mathrm{C}$ BP $(1750-$ 940 cal BP) (Figs. 3 and 8). Coincidence between the two records occurs between 1750 and $1460 \mathrm{cal}$ BP (Fig. 8). The interpreted higher wave activity between 1750 and $1460 \mathrm{cal}$ $\mathrm{BP}$ in the raised beach record corresponds to more openwater conditions to the east around $2000{ }^{14} \mathrm{C} \mathrm{BP}(2030 \mathrm{cal}$ $\mathrm{BP}$ ) on the basis of the driftwood/whalebone record.

Though the Coburg and North Water polynyas at the north end of Baffin Bay are somewhat distant from Lowther

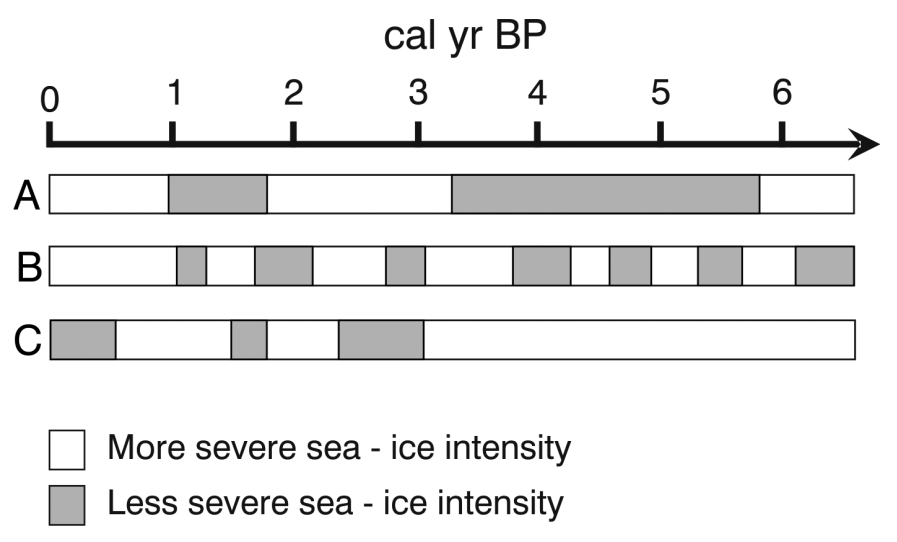

FIG. 8. Comparison of reconstructed sea-ice histories from (a) the spatiotemporal distribution of bowhead whale bones and driftwood (Dyke et al., 1996), (b) palaeotransfer functions from dinoflagellate cyst assemblages (Mudie et al., 2005), and (c) the morphology and sedimentology of raised beaches (this study).

Island, the record of sea-ice variability there (Mudie et al., 2005) shows partial correlation with our interpretation derived from the raised beach sequences. Cores from the North Water Polynya show more open water in the past 175 calendar years and again in the earlier part of the last millennium and another interval of reduced sea ice between 2900 and $2400{ }^{14} \mathrm{C}$ BP (3270 and $2550 \mathrm{cal} \mathrm{BP}$ ) (Mudie et al., 2005:120), consistent with Unit $C$ beaches on Lowther Island. On the other hand, the North Water record shows additional intervals of more open water before $3000{ }^{14} \mathrm{C} \mathrm{BP}$ (3030 cal BP) and a general trend to more open water back in time. The Coburg Polynya core shows more ice from 3400 to $2900{ }^{14} \mathrm{C}$ BP $(3750-3060$ cal BP), less ice from 2900 to $2500{ }^{14} \mathrm{C}$ BP $(3060-2740 \mathrm{cal} \mathrm{BP})$, more ice from 2500 to $2100{ }^{14} \mathrm{C}$ BP $(2740-2150 \mathrm{cal} \mathrm{BP})$, less ice from 2100 to 1700 ${ }^{14} \mathrm{C}$ BP $(2150-1680 \mathrm{cal} \mathrm{BP})$, and increased ice from 1700 to $900{ }^{14} \mathrm{C}$ BP (1680-840 cal BP (Mudie et al., 2005:119), a pattern with some similarities to the conditions suggested by Units B, B', C, and D on Lowther Island (Fig. 8). More variable conditions occurred before $3400{ }^{14} \mathrm{C}$ BP $(3750 \mathrm{cal}$ $\mathrm{BP})$, with a trend, similar to that seen in the North Water Polynya, to less ice lower in the core.

The discrepancies between these proxy sea-ice histories may have several causes. First, our age-elevation model is dependent on the precision of the RSL record (see Relative Sea-level History). However, this factor would slightly affect the age limits of the designated sea-ice periods only, and not the overall pattern. Second, it must be acknowledged that sea ice and related wave climate are not the sole controls on Arctic beach morphology. Important local and regional forcing factors include the rate and direction of RSL change, accommodation space, and sediment supply, among others (Carter et al., 1989; Forbes et al., 1995; Orford et al., 1996, 2002). In this specific case study, however, morphological units are consistent around the island, despite significant variations in slope values (Table 1), orientation, and the source and quantity of sediment supply from one site to another. Unless the rate and direction of RSL change have undergone marked fluctuations during the late 
Holocene, it is concluded that sea-ice intensity, through its impact on wave climate, has been the predominant control on beach morphology at Lowther Island over the last 6500 calendar years. Third, there may be inconsistencies in the spatial resolution of both proxy sea-ice records. The record of Dyke and colleagues is based on bowhead whale skulls collected across the central CAA, from M'Clintock Channel in the west to Lancaster Sound and Navy Board Inlet in the east (Dyke et al., 1996). The highly variable summer seaice conditions across this large region today perhaps existed throughout the late Holocene. If so, the localized record of sea-ice occurrence, represented by beach morphodynamics, may not necessarily be compatible with the regional sea-ice history derived from the spatial distribution of bowhead whale remains (Dyke et al., 1996) or the local record derived from biomarkers for eastern Barrow Strait (Vare et al., 2009).

In summary, consistent variations in raised-beach morphology and sedimentology across Lowther Island in the central Canadian Arctic Archipelago are considered to be a proxy record of sea-ice concentration (and conversely of extent of open water and potential wave energy). The localized nature of this proxy sea-ice record precludes extrapolation of results to a larger regional scale. Local leads along a shoreline can indeed lead to the deposition of a beach ridge despite extensive sea-ice cover on a regional scale. Such a scenario may explain the deposition of the small beach ridges forming Units $\mathrm{B}$ and $\mathrm{D}$, and may also account for the stranding of bowhead whale remains during periods of extensive sea-ice cover.

\section{ACKNOWLEDGEMENTS}

We wish to thank Zack Bartlett for his unstinting help on Lowther Island under trying weather conditions. Logistical support from the Polar Continental Shelf Program (PCSP) and PCSP staff in Resolute played key roles in the field program. Gavin Manson (Geological Survey of Canada) assisted with processing of the QuickBird image and Charlie Conway (Memorial University) provided technical assistance with figure preparation. Bob Taylor and Art Dyke (Geological Survey of Canada) supported the work with valuable advice throughout the project, and they and three journal referees provided helpful comments on earlier versions of the manuscript. This work is supported by ArcticNet and the Networks of Centres of Excellence; Natural Resources Canada, through the Climate Change Geoscience Program of the Earth Sciences Sector (ESS) and the Polar Continental Shelf Program (PCSP); the Natural Sciences and Engineering Research Council of Canada; and the Association of Canadian Universities for Northern Studies, through the Garfield Weston Award for Northern Research. This paper is ESS contribution number 20090112 and PCSP contribution number 04209.

\section{REFERENCES}

Barnes, P.W., Kempema, E.W., Reimnitz, E., McCormick, M., Weber, W.S., and Hayden, E.C. 1993. Beach profile modification and sediment transport by ice: An overlooked process on Lake Michigan. Journal of Coastal Research 9(1):65-86.

Barrie, W.B., Bornhold, B.D., Hodgson, D.A., Jubb, R.G., McLaren, P., and Taylor, R.B. 1979. Coastal reconnaissance for marine terminal planning in the High Arctic, District of Franklin. Geological Survey of Canada, Open File 633. 328 p.

Berkman, P.A., Andrews, J.T., Björck, S., Colhoun, E.A., Emslie, S.D., Goodwin, I.D., Hall, B.L., et al. 1998. Circum-Antarctic coastal environmental shifts during the Late Quaternary reflected by emerged marine deposits. Antarctic Science 10(3):345-362.

Brückner, H., and Schellmann, G. 2003. Late Pleistocene and Holocene shorelines of Andréeland, Spitsbergen (Svalbard) geomorphological evidence and palaeo-oceanographic significance. Journal of Coastal Research 19(4):971 -982.

Brückner, H., Schellmann, G., and van der Borg, K. 2002. Uplifted beach ridges in northern Spitsbergen as indicators for glacio-isostasy and palaeo-oceanography. Zeitschrift für Geomorphologie 46(3):309-336.

Butler, E.R.T. 1999. Process environments on modern and raised beaches in McMurdo Sound, Antarctica. Marine Geology 162:105-120.

Carter, R.W.G. 1988. Coastal environments. London: Academic Press. 617 p.

Carter, R.W.G., and Orford, J.D. 1984. Coarse clastic barrier beaches: A discussion of the distinctive dynamic and morphosedimentary characteristics. Marine Geology 60: $377-389$.

1993. The morphodynamics of coarse clastic beaches and barriers: A short- and long-term perspective. Journal of Coastal Research Special Issue 15:158-179.

Carter, R.W.G., Forbes, D.L., Jennings, S.C., Orford, J.D., Shaw, J., and Taylor, R.B. 1989. Barrier and lagoon coast evolution under differing relative sea-level regimes: Examples for Ireland and Nova Scotia. Marine Geology 88:221-242.

Church, J.A., and White, N.J. 2006. A 20th century acceleration in global sea-level rise. Geophysical Research Letters 33, L01602, doi:10.1029/2005GL024826.

Cooper, J.A.G., and Navas, F. 2004. Natural bathymetric change as a control on century-scale shoreline behavior. Geology 32(6):513-516.

Cowell, P.J., and Thom, B.G. 1994. Morphodynamics of coastal evolution. In: Carter, R.W.G., and Woodroffe, C.D., eds. Coastal evolution: Late Quaternary shoreline morphodynamics. Cambridge: Cambridge University Press. 33-86.

deSève, M. 1999. Transfer function between surface sediment diatom assemblages and sea-surface temperature and salinity of the Labrador Sea. Marine Micropalentology 36:249-267.

Dionne, J.-C. 1976. Le glaciel dans la région de la Grande Rivière, Québec subarctique. La Revue de Géographie de Montréal 30(1-2):133-153. 
1992. Ice-push features. Canadian landform examples-25. The Canadian Geographer 36(1):86-91, doi:10.1111/j.1541-00 64.1992.tb01122.x.

Dyke, A.S. 1993. Glacial and sea-level history of Lowther and Griffith islands, Northwest Territories: A hint of tectonics. Géographie Physique et Quaternaire 47(2):133 - 145.

Dyke, A.S., and England, J. 2003. Canada's most northerly postglacial bowhead whales (Balaena mysticetus): Holocene sea-ice conditions and polynya development. Arctic 56(1): $14-20$.

Dyke, A.S., Morris, T.F., and Green, D.E.C. 1991. Postglacial tectonic and sea level history of the central Canadian Arctic. Geological Survey of Canada, Bulletin 397. 56 p.

Dyke, A.S., Hooper, J., and Savelle, J.M. 1996. A history of sea ice in the Canadian Arctic Archipelago based on postglacial remains of the bowhead whale (Balaena mysticetus). Arctic 49(3):235-255.

Dyke, A.S., England, J., Reimnitz, E., and Jetté, H. 1997. Change in driftwood delivery to the Canadian Arctic Archipelago: The hypothesis of postglacial oscillations of the Transpolar Drift. Arctic 50(1):1-16.

Fletcher, C.H., Fairbridge, R.W., Møller, J.J., and Long, A.J. 1993. Emergence of the Varanger Peninsula, Arctic Norway, and climate changes since deglaciation. The Holocene 3(2): $116-127$.

Forbes, D.L., and Syvitski, J.P.M. 1994. Paraglacial coasts. In: Carter, R.W.G., and Woodroffe, C.D., eds. Coastal evolution: Late Quaternary shoreline morpho-dynamics. Cambridge: Cambridge University Press. 373-424.

Forbes, D.L., and Taylor, R.B. 1987. Coarse-grained beach sedimentation under paraglacial conditions, Canadian Arctic coasts. In: FitzGerald, D.M., and Rosen, P.S., eds. Glaciated coasts. San Diego: Academic Press. 51-86.

. 1994. Ice in the shore zone and the geomorphology of cold coasts. Progress in Physical Geography 18(1):59-89, doi: 10.1177/030913339401800104.

Forbes, D.L., Orford, J.D., Carter, R.W.G., Shaw, J., and Jennings, S.C. 1995. Morphodynamic evolution, self-organization and instability of coarse-clastic barriers on paraglacial coasts. Marine Geology 126:63-85.

González Bonorino, G., Bujalesky, G., Colombo, F., and Ferrero, M. 1999. Holocene coastal paleoenvironments in Atlantic Patagonia, Argentina. Journal of South American Earth Sciences 12:325-331.

Grumet, N.S., Wake, C.P., Mayewski, P.A., Zielinski, G.A., Whitlow, S.I., Koerner, R.M., Fisher, D.A., and Woollett, J.M. 2001. Variability of sea-ice extent in Baffin Bay over the last millennium. Climatic Change 49:129-145.

Hansom, J.D. 2001. Coastal sensitivity to environmental change: A view from the beach. Catena 42:291-305.

Héquette, A., and Barnes, P.W. 1991. Coastal retreat and shoreface profile variations in the Canadian Beaufort Sea. Marine Geology 91:113-132.

Hughen, K.A., Baillie, M.G.L., Bard, E., Beck, J.W., Bertrand, C.J.H., Blackwell, P.G., Buck, C.E., et al. 2004. Marine04 marine radiocarbon age calibration, $0-26$ cal kyr BP. Radiocarbon 46(3):1059-1086.
Hume, J.D., and Schalk, M. 1976. The effect of ice on the beach and nearshore, Point Barrow, Arctic Alaska. La Revue de Géographie de Montréal 30(1-2):105-114.

Jennings, S., and Smyth, C. 1990. Holocene evolution of the gravel coastline of East Sussex. Proceedings of the Geological Association 101(3):213-224.

Katsuki, K., and Takahashi, K. 2005. Diatoms as paleoenvironmental proxies for seasonal productivity, sea-ice and surface circulation in the Bering Sea during the late Quaternary. Deep-Sea Research Part II: Topical Studies in Oceanography 52(16-18):2110-2130.

Kinnard, C., Zdanowicz, C.M., Fisher, D.A., and Wake, C.P. 2006. Calibration of an ice-core glaciochemical (sea-salt) record with sea-ice variability in the Canadian Arctic. Annals of Glaciology 44(1):383-390.

Levac, E., DeVernal, A., and Blake, W. 2001. Sea-surface conditions in northernmost Baffin Bay during the Holocene: Palynological evidence. Journal of Quaternary Science 16: $353-363$.

Martini, I.P. 1980. Sea ice generated features of coastal sediments of James Bay, Ontario. Proceedings, Canadian Coastal Conference 80 (Burlington). Ottawa: National Research Council. 93-102.

Mason, O.K., and Jordan, J.W. 1993. Heightened North Pacific storminess during synchronous late Holocene erosion of northwest Alaska beach ridges. Quaternary Research 40(1): 55-69.

McCann, S.B. 1973. Beach processes in an Arctic environment. Coastal Geomorphology, Proceedings of the 3rd Annual Geomorphology Symposia Series, Binghampton, New York. $141-155$.

McKenzie, P. 1958. The development of beach sand ridges. The Australian Journal of Science 20:213-214.

Melville, G. 1984. Headlands and offshore islands as dominant controlling factors during late Quaternary barrier formation in the Forster-Tuncurry area, New South Wales, Australia. Sedimentary Geology 39:243-271.

Moign, A. 1976. L'action des glaces flottantes sur le littoral et les fonds marins du Spitsberg central et nord-occidental. La Revue de Géographie de Montréal 30(1-2):51-64.

Møller, J.J., Yevzerov, V.Y., Kolka, V.V., and Corner, G.D. 2002. Holocene raised-beach ridges and sea-ice-pushed boulders on the Kola Peninsula, northwest Russia: Indicators of climatic change. The Holocene 12(2):169-176.

Mudie, P.J., Rochon, A., and Levac, E. 2005. Decadal-scale sea ice changes in the Canadian Arctic and their impacts on humans during the past 4,000 years. Environmental Archaeology 10(2):113-126.

Nichols, R.L. 1961. Characteristics of beaches formed in polar climate. American Journal of Science 259:694-708.

Orford, J.D. 1977. A proposed mechanism for storm beach sedimentation. Earth Surface Processes 2:381-400.

Orford, J.D., Carter, R.W.G., and Jennings, S.C. 1991. Coarse clastic barrier environments: Evolution and implications for Quaternary sea-level interpretation. Quaternary International 9:87-104. 
1996. Control domains and morphological phases in gravel-dominated coastal barriers of Nova Scotia. Journal of Coastal Research 12(3):589-604.

Orford, J.D., Forbes, D.L., and Jennings, S.C. 2002. Organizational controls, typologies and time scales of paraglacial graveldominated coastal systems. Geomorphology 48:51 -85.

Owens, E.H. 1976. The effects of ice on the littoral zone at Richibucto Head, eastern New Brunswick. La Revue de Géographie de Montréal 30(1-2):95-104.

Owens, E.H., and McCann, S.B. 1970. The role of ice in the Arctic beach environment with special reference to Cape Ricketts, southwest Devon Island, NWT, Canada. American Journal of Science 268(5):397-414.

Powers, M.C. 1953. A new roundness scale for sedimentary particles. Journal of Sedimentary Petrology 23(2):117-119.

Reimer, P.J., Baillie, M.G.L., Bard, E., Bayliss, A., Beck, J.W., Bertrand, C.J.H., Blackwell, P.G., et al. 2004. IntCal04 terrestrial radiocarbon age calibration, $0-26$ cal kyr BP. Radiocarbon 46(3):1029-1058.

Reimnitz, E., Barnes, P.W., and Harper, J.R. 1990. A review of beach nourishment from ice transport of shoreface materials, Beaufort Sea, Alaska. Journal of Coastal Research 6(2): $439-470$.

Roy, P.S., Cowell, P.J., Ferland, M.A., and Thom, B.G. 1994. Wave-dominated coasts. In: Carter, R.W.G., and Woodroffe, C.D., eds. Coastal evolution: Late Quaternary shoreline morphodynamics. Cambridge: Cambridge University Press. $121-196$.

Sanjaume, E., and Tolgensbakk, J. 2009. Beach ridges from the Varanger Peninsula (Arctic Norwegian coast): Characteristics and significance. Geomorphology 104:82-92.

St. Hilaire, D., Taylor, R.B., Forbes, D.L., and Bell, T. 2007. The impacts of a storm on emergent Arctic gravel beaches, Cornwallis Island, Nunavut. Proceedings of Arctic Coastal Zones at Risk Workshop, 1-3 October 2007, Tromsø, Norway. $71-74$.

Stuiver, M., Reimer, P.J., and Reimer, R. 2005. CALIB radiocarbon calibration, Version 5.0.2html. Updated (March 2010) version 6.0html available at http://calib.qub.ac.uk/calib/.

Taylor, R.B. 1978a. The occurrence of grounded ice ridges and shore ice piling along the northern coast of Somerset Island, NWT. Arctic 31(2):133-149.

- 1978b. Lowther Island. In: Barrie, W.B., Bornhold, B.D., Hodgson, D.A., Jubb, R.G., McLaren, P., and Taylor, R.B. Coastal reconnaissance for marine terminal planning in the
High Arctic. Vol. I - Main report. Ottawa: Geological Survey of Canada. Unpublished report to Transport Canada (later published as Open File 633). 144-160.

- 1981. Observations of storm conditions in the coastal zone, Bylot Island, N.W.T. Proceedings of the Workshop on Ice Action on Shores, Rimouski. Ottawa: National Research Council. 133-149.

Taylor, R.B., and Forbes, D.L. 1987. Ice dominated shores of Lougheed Island: Type examples for the northwest Queen Elizabeth Islands, Arctic Canada. Proceedings of the Canadian Coastal Conference 87, Quebec City. Ottawa: National Research Council. 33-48.

Taylor, R.B., and Frobel, D. 2006. Cruise report 2005-305: 2005 field survey of coastal changes along Barrow Strait, Bylot and northern Baffin islands, Nunavut. Open File Report 5395. Dartmouth, Nova Scotia: Geological Survey of Canada. 89 p.

Taylor, R.B., and McCann, S.B. 1976. The effect of sea and nearshore ice on coastal processes in the Canadian Arctic Archipelago. La Revue de Géographie de Montréal 30(12):123-132.

- 1983. Coastal depositional landforms in northern Canada. In: Dawson, S., ed. Shorelines and isostasy. Special Publication 16. London: Institute of British Geographers. 53-77.

Teller, J.T. 2001. Formation of large beaches in an area of rapid differential isostatic rebound: The three-outlet control of Lake Agassiz. Quaternary Science Reviews 20:1649-1659.

Thorsteinsson, R. 1986. Geology of Cornwallis Island and neighbouring smaller islands, Canadian Arctic Archipelago, District of Franklin, Northwest Territories. Geological Survey of Canada, Map 1626A, 1: 250000.

Vare, L.L., Massé, G., Gregory, T.R., Smart, C.W., and Belt, S.T. 2009. Sea ice variations in the central Canadian Arctic Archipelago during the Holocene. Quaternary Science Reviews 28:1354-1366, doi:10.1016/j.quascirev.2009.01.013.

Washburn, A.L. 1947. Reconnaissance geology of portions of Victoria Island and adjacent regions, Arctic Canada. Geological Society of America, Memoir 22. 142 p.

Wells, L.E. 1996. The Santa beach-ridge complex: Sea-level and progradational history of an open gravel coast in central Peru. Journal of Coastal Research 12:1-17.

Wentworth, C.K. 1922. A scale of grade and class terms for clastic sediments. The Journal of Geology 30(5):377-392.

Wright, L.D., and Thom, B.G. 1977. Coastal depositional landforms: A morphodynamic approach. Progress in Physical Geography 1(3):412-459. 